\title{
WIND POTENTIAL ASSESSMENT OVER MOROCCO'S MARRAKESH - SAFI REGION IN 2021-2050 BASED ON THE RCM S FORECASTS AS PART OF THE CORDEX-AFRICA PROJECT
}

\author{
Y. El Hadri, M. Slizhe, K. Sernytska \\ Odessa State Environmental University, \\ 15 Lvivska str., Odesa, Ukraine, 65016,magribinets@ukr.net
}

\begin{abstract}
The purpose of the study is to determine the features of the spatial distribution of the wind speed in Marrakesh - Safi region in 2021-2050, as well as the distribution of the specific power of the wind flow at various altitudes above the earth's surface to determine the wind class of the area in the coming decades. Currently, the region has two large wind farms: Essaouira-Amogdoul and Tarfayer. To assess the future state of climate in Marrakesh - Safi region, the results of calculations of regional climate models (RCM) of the CORDEX-Africa project for the period 2021-2050 were used. The RCM modeling was carried out for the region of Africa, in a rectangular coordinate system with a spatial resolution of $\sim 44 \mathrm{~km}$. Model calculation was performed taking into account the greenhouse gas concentration trajectory of RCP 4.5. As a result of simulation for the period 2021-2050, mean monthly values of wind speed "sfcWind" $\left(\mathrm{m} \cdot \mathrm{s}^{-1}\right)$ and the daily maximum near-surface wind speed "sfcwindmax" $\left(\mathrm{m} \cdot \mathrm{s}^{-1}\right)$ at $10 \mathrm{~m}$ height were obtained. Then, based on the wind speed rows, the values of the wind power density at a height of $50 \mathrm{~m}$ and $100 \mathrm{~m}$ were calculated. The results of model calculations of wind speed showed that the ensemble mean of wind speed for the period 2021-2050 will be from $3.8 \mathrm{~m} \cdot \mathrm{s}-1$ in Kelaat Sraghna Province to $7.2 \mathrm{~m} \cdot \mathrm{s}-1$ on the stretch of the Atlantic coast between Cap Sim and Cap Tafelny.The distribution over the territory will be influenced by proximity to the ocean, models predict the highest wind speeds on the coast, and when moving deep into the region, the wind speed will decrease.The analysis of simulation results showed that in the coastal areas of the region favorable conditions in terms of wind energy development will remain, and the highest wind speeds of the model are predicted on the Atlantic coast between Cap Sim and Cap Tafelny. By the size of the specific power of the wind flow, significant wind resources will have the territory lying along the coast from Cap Sim to the southern border of the region, and in the area of the power plants EssaouiraAmogdoul and Tarfayer models predict the conditions corresponding to the outstanding wind power class.
\end{abstract}

Keywords: CORDEX-Africa; wind speed; Wind Power Density; RCM; Morocco, Marrakesh - Safi.

\section{INTRODUCTION}

Today, Morocco has a tendency to increase its energy consumption, as a result of industrial development, demographic growth and changes in people's living standards. By 2040, Morocco's population is expected to reach 40 million, mostly in urban areas [1]. The impact of climate change is already leading to the movement and migration of people across the country. This will entail an additional environmental impact in Morocco. In addition, in recent decades there was a need to quickly address the urgent environmental problems associated with increased levels of greenhouse gas emissions into the atmosphere. In this context, the timely assessment of possible changes in the potential of wind energy in Morocco is an urgent issue that will ensure its energy security in the future. Today, it is possible to obtain such information by modelling future climate conditions using climate models.

The Moroccan Government has developed the National Energy Strategy, which includes the Moroccan Integrated Wind Energy Program. One of the priorities of this program is to increase the share of renewable technologies in the country's energy sector. In addition, Morocco launched the renewable energy development program [2], which aims to achieve a total installed capacity $2000 \mathrm{MW}$ from wind power, $2000 \mathrm{MW}$ from solar energy and an increase in the capacity of hydropower to $2000 \mathrm{MW}$ by 2020 , with further increase of installed renewable capacity to $10 \mathrm{GW}$ to meet the target to generate $52 \%$ of energy from renewable sources by 2030 $[3,4]$. Today, the course of development of European energy is resolutely aimed at a complete transi- 
tion to renewable energy sources. Some of the needs of European consumers are planned to be covered by the transportation of electricity generated by wind and solar power plants in Morocco to Europe. For this in 2018 the World Bank accepted the project with a total cost US\$2257.00 million for Morocco's adoption of innovative solar technology, as part of the national goal of developing the country's world-class solar and wind energy resources. This assistance includes US\$420.00 million from EU (European Investment Bank), US\$180.00 million from the French Government (Govt. of [MOFA and AFD (C2D)]), US\$852.00 million from the German Federal Government (Kreditanstalt Fur Wiederaufbau). Thus, the results of the study of the impact of climate change on renewable resources in Morocco are of interest not only for the Moroccan side, but also for stakeholders in the EU.

The study of the wind regime in Morocco was carried out by a group of Moroccan scientists from Mohammed V University [5-7]. Scientists evaluated wind characteristics and wind potential of Morocco from 1978-1989, 1998 and 1993-1994. As a result of the analysis, the distribution of wind speed across the country was constructed and it was concluded that the most favorable wind power areas are the Gibraltar region and the Atlantic coast areas between the cities of Laayoune and Dakhla, and between Casablanca and Agadir.

The purpose of the study is to determine the features of the spatial distribution of the wind speed in Marrakesh - Safi region in 2021-2050, as well as the distribution of the specific power of the wind flow at various altitudes above the earth's surface to determine the wind class of the area in the coming decades.

\section{MATERIALS AND METHODS OF RESEARCH}

\subsection{Study Area}

Marrakesh - Safi region covers an area of $38445 \mathrm{~km}^{2}$ and is located on the Atlantic coast of Morocco, at a latitude between $30^{\circ} 45^{\prime} \mathrm{N}$ and $32^{\circ} 50^{\prime}$ N. (Fig. 1). In the south and southeast of the region there are the High Atlas ranges, the height of which reaches $4167 \mathrm{~m}$ (Mount Toubkal). The population of the region in 2014 was 4520569 people, of which $69 \%$ live in cities [8].

Currently, the region has two large wind farms: Essaouira-Amogdoul and Tarfayer (Table 1), which are included to the Moroccan Integrated Wind Program [9].

\subsection{Data Source}

To assess the future state of climate in Marrakesh - Safi region, the results of calculations of regional climate models (RCM) of the CORDEXAfrica project for the period 2021-2050 were used [10].

The RCM modeling was carried out for the region of Africa, in a rectangular coordinate system with a spatial resolution of $\sim 44 \mathrm{~km}$. Model calculation was performed taking into account the greenhouse gas concentration trajectory of RCP 4.5. 11 climate models were used for the calculation (Table 2).

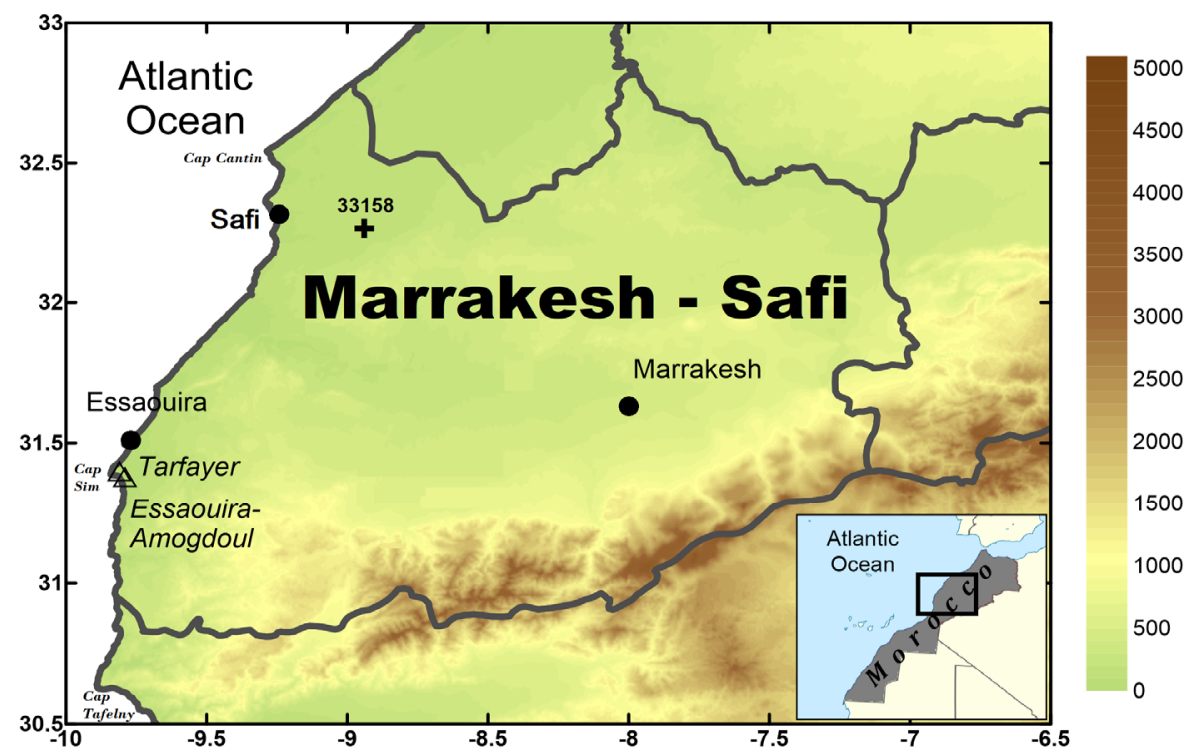

Fig. 1 - Area of study (triangles marked the location of wind farms Essaouira-Amogdoul and Tarfayer) 
Table 1 - Essaouira-Amogdoul and Tarfayer wind farms characteristics [12]

\begin{tabular}{|c|c|c|c|}
\hline Wind farm name & Details & Status & Coordinates \\
\hline $\begin{array}{l}\text { Essaouira-Amogdoul } \\
\text { (YNNA Bio Power) }\end{array}$ & $\begin{array}{l}71 \text { turbines: Gamesa G52/850 } \\
\text { (power } 850 \mathrm{~kW} \text {, diameter } 52 \mathrm{~m} \text { ); } \\
\text { Total nominal power: } 60.35 \mathrm{MW} \text {; } \\
\text { Onshore wind farm }\end{array}$ & Under construction & $\begin{array}{c}31^{\circ} 22^{\prime} 44.7^{\prime \prime} \mathrm{N} ; \\
-9^{\circ} 47^{\prime} 7.6^{\prime \prime} \mathrm{E}\end{array}$ \\
\hline $\begin{array}{l}\text { Tarfayer } \\
\text { (Essaouira) }\end{array}$ & $\begin{array}{l}71 \text { turbines: Gamesa G52/850 } \\
\text { (power } 850 \mathrm{~kW} \text {, diameter } 52 \mathrm{~m} \text { ); } \\
\text { Total nominal power: } 60.35 \mathrm{MW} \text {; } \\
\text { Onshore wind farm }\end{array}$ & $\begin{array}{c}\text { Commissioning: } 2007 \\
\text { Operational }\end{array}$ & $\begin{array}{l}31^{\circ} 23^{\prime} 50.2^{\prime \prime} \mathrm{N} \\
-9^{\circ} 48^{\prime} 24.3^{\prime \prime} \mathrm{E}\end{array}$ \\
\hline
\end{tabular}

Table 2 - Regional climate models characteristics

\begin{tabular}{|c|c|c|c|}
\hline $\begin{array}{c}\text { No of } \\
\text { model }\end{array}$ & Model name & $\begin{array}{c}\text { The Atmospheric General } \\
\text { Circulation Model }\end{array}$ & Data Centre \\
\hline M1 & KNMI-ICHEC-EC-EARTH & IFS & CNRM, France \\
\hline M2 & CanESM2 & CanCM4 & CCCMA, Canada \\
\hline M3 & CNRM-CM5 & ARPEGE & CNRM / CERFACS, France \\
\hline M4 & SMHI-ICHEC-EC-EARTH & IFS & CNRM, France \\
\hline M5 & CSIRO Mark 3.6 & Mk3 AGCM & IPSL, France \\
\hline M6 & IPSL-CM5A-MR & LMDZ & AORI/NIES/JAME S\&T, Japan \\
\hline M7 & MIROC5 & AGCM CCSR & Hadley Center, UK \\
\hline M8 & HadGEM2-ES & HadGEM2-A & NCC, Norway \\
\hline M9 & MPI-ESM-LR & ECHAM6 & GFDL, USA \\
\hline M10 & NorESM1 & CAM4-Oslo & AM3 \\
\hline M11 & GFDL-ESM2M & & \\
\hline \hline
\end{tabular}

As a result of simulation for the period 20212050, mean monthly values of wind speed "sfcWind" $\left(\mathrm{m} \cdot \mathrm{s}^{-1}\right)$ and the daily maximum nearsurface wind speed "sfcwindmax" $\left(\mathrm{m} \cdot \mathrm{s}^{-1}\right)$ at $10 \mathrm{~m}$ height were obtained.

\subsection{The wind power density}

The wind power density is a climate characteristic that allows an assessment of the wind potential of a specific area, as well as providing a justification for using the layout and design of wind turbines [11]. The wind power density depends on the distribution of the repeatability of wind speeds and the nature of the underlying surface in a particular area.The most accurate description of the wind speed for flat terrain conditions can be obtained using Weibull distribution [11]:

$$
f(u)=\frac{\gamma}{\beta}\left(\frac{u}{\beta}\right)^{\gamma-1} \exp \left[-\left(\frac{u}{\beta}\right)^{\gamma}\right],
$$

where $f(u)$ is the frequency of occurrence of wind speed $\mathrm{u}, \beta$ - scaling factor $\left(\mathrm{m} \cdot \mathrm{s}^{-1}\right)(\beta=1.1 \bar{u}), \gamma-$ the shape factor, which is describes the shape of the distribution. Factor $\gamma$ is calculated by the expression [7]

$$
\gamma=C_{u}^{-1.086}
$$

where $C_{u}$ - coefficient of variation, $\left(C_{u}=\sigma / \bar{u}\right)$. Weibull distribution, in the case when the factor $\gamma=1$, called the exponential distribution, at $\gamma=2-$ the Rayleigh distribution, at $\gamma=3$ distribution is approaching to Normal (Gaussian) distribution [13]. Since, the observed values of the wind show the frequency distributions, which are well described using the Rayleigh distribution, the manufacturers use this distribution when calculating standard performance indicators for wind turbines. The size of the factor $\gamma$ is influenced by the local wind climate and the landscape of the terrain for which calculations are carried out. Low factor value $\gamma<1.8$ is typical for wind climates with a high content of thermal winds. High factor value $\gamma>2.5$ is characteristic for very constant wind climates (for example, trade winds). Both factor, $\beta$ and $\gamma$, depend on the height above the underlying surface, up to a height of $100 \mathrm{~m}$, their values increase, above $100 \mathrm{~m}$ the value of the factor $\gamma$ decreases [11]. 
In this study, the estimate of the wind power density was performed using the formula [11]:

$$
N_{e}=\frac{1}{2} \rho \beta^{3} \Gamma\left(\frac{3}{\gamma}+1\right)
$$

where $N e$ - wind power density, $\rho$ - air density $\left(1.226 \mathrm{~kg} \cdot \mathrm{m}^{-3}\right), \quad \Gamma\left(\frac{3}{\gamma}+1\right)-$ gamma function. To calculate gamma function was used interpolation expression, which for value $\mathrm{x}<60$ has an error less $10^{-4}[11]$ :

$$
\Gamma(x) \cong \frac{\sqrt{\frac{2 \pi}{y}} \exp \left\{y[\ln (y)-1]+\frac{1}{12 y}\right\}}{x(x+1)(x+2)(x+3)(x+4)(x+5)},
$$

where $\mathrm{y}=\mathrm{x}+6$.

The calculation of the predicted wind power density for the period 2021-2050 was performed using expressions (3) - (4). As a base value of the wind speed was used value of wind speed calculated by the ensemble of the regional climate models of the CORDEX-Africa project $[10,14]$. The factor $\gamma$ was adopted at 2.5 , based on the considerations that much of Morocco's territory was affected by trade winds during the year. In calculating of the wind power density we are proceed from the assumption that climate change will only manifest itself in changing the value of the wind speed while maintaining its distribution factors, so the results provide an approximate estimate of the future power of the wind flow.

Calculation of wind speed at $50 \mathrm{~m}$ and $100 \mathrm{~m}$ height above the earth's surface was done using the expression (5) [15]

$$
\frac{u_{2}}{u_{1}}=\left(\frac{h_{2}}{h_{1}}\right)^{m}
$$

$u_{1}$ and $u_{2}$ are the wind speeds at heights $h_{1}$ and $h_{2}, m$ - the wind shear exponent, which is depends on height $h$, surface roughness, atmospheric stability, orography, and season of the year. On average accept $m=0.14$.

Then, based on the values of wind speed at an altitude of $50 \mathrm{~m}$ and $100 \mathrm{~m}$ above the earth's surface, wind power density $(\mathrm{Ne})$ was calculated at these heights, and using the criteria (Table 3), the wind class of the study region in 2021-2050 was determined.
Table 3 - Classes of wind power density [16]

\begin{tabular}{|c|c|c|}
\hline \multirow{2}{*}{$\begin{array}{c}\text { Wind power } \\
\text { class }\end{array}$} & $\begin{array}{c}\text { Wo } \mathbf{~ m} \text { height } \\
\text { density, } \\
\mathbf{W} \cdot \mathbf{m}^{-2}\end{array}$ & $\begin{array}{c}\text { Mean wind } \\
\text { speed, } \mathbf{~ m} \cdot \mathbf{s}^{-1}\end{array}$ \\
\cline { 2 - 3 } Poor & $<200$ & $<5.6$ \\
\hline Marginal & $200-300$ & $5.6-6.4$ \\
\hline Fair & $300-400$ & $6.4-7.0$ \\
\hline Good & $400-500$ & $7.0-7.5$ \\
\hline Excellent & $500-600$ & $7.5-8.0$ \\
\hline Outstanding & $600-800$ & $8.0-8.8$ \\
\hline Superb & $>800$ & $>8.8$ \\
\hline
\end{tabular}

The area suitable for large wind farms should be of wind energy class 4 or higher [16].

\subsection{Daily Maximum Wind Speed and Gust Factor}

The daily maximum wind speed (DMWS) is the highest daily value of the wind speed from the number of urgent observations and represents the maximum wind gust recorded at the station in one of the observation periods. DMWS is closely related to economic losses and risks. In the event of a sudden turbulent gust, wind speed, turbulence and wind shear can change dramatically. The resulting imbalance of the rotor while maintaining the output power of the generator and a large inertia of mechanical components lead to an imbalance of the load and speed of the generator, and consequently, oscillations and rocking of the wind turbine tower [16], which leads to a rapid failure of its components.

In RCM, the DMWS is taken to be the maximum of four instant wind speeds calculated for 00:00, 06:00, 12:00 and 18:00 UTC. Different RCMs use different approaches to calculate the daily maximum wind speed. For example, the SMHI model takes into account turbulent kinetic energy, mean wind and static stability in the boundary layer, the KNMIRACMO2 model calculates the rate of wind gusts, adding to a wind speed at a height of $10 \mathrm{~m}$ component that contains static stability in the boundary layer of the atmosphere, calculating the MPI- REMO are based on empirical assumptions, taking into account turbulent kinetic energy in the lowest layer of the model [17] .

The relation of the DMWS with the daily mean wind speeds can be established with the help of the peak-gust factor [18], which is calculated as the ratio

$$
G=\frac{u_{g}}{\bar{u}}-1
$$


where $G$ - the peak-gust factor, $u_{g}$ - the daily peak-gust wind speed, and $\bar{u}$ - the daily mean wind speed. $G$ is a dimensionless quantity that takes the value $0 \leq G<+\infty$ (with $G=0$, when $u_{g}=\bar{u}$ ).

When averaged for a certain period of time, $G$ reflects the climatic impulse of the wind. Studies show that $G$ is sensitive to meteorological conditions, for example, as a rule, its value decreases as the mean wind speed increases. The surface roughness affects $G$, it takes higher values over rough surfaces. $G$ is influenced by the state of atmospheric stability, the magnitude $G$ increases with decreasing atmospheric stability, although this effect is not as strong as the connection $G$ with the average wind [19].

\section{RESULTS AND DISCUSSION}

\subsection{Spatial distribution of wind speed in 2021- 2050}

The results of model calculations of wind speed showed that the ensemble mean of wind speed for the period 2021-2050 will be from $3.8 \mathrm{~m} \cdot \mathrm{s}^{-1}$ in Kelaat Sraghna Province to $7.2 \mathrm{~m} \cdot \mathrm{s}^{-1}$ on the stretch of the Atlantic coast between Cap Sim and Cap Tafelny (Fig. 2a.).The distribution over the territory will be influenced by proximity to the ocean, models predict the highest wind speeds on the coast, and when moving deep into the region, the wind speed will decrease.

Based on the fact that in the first approximation, the wind energy potential can be estimated at the level of average annual wind speed, which should be $\geq 5 \mathrm{~m} \cdot \mathrm{s}^{-1}$ at an altitude of $10 \mathrm{~m}$ above the earth's surface [17], it follows that in the coming decades, favorable conditions for the development of wind power will remain in the coastal areas of the region.

The annual run of wind speed is of great importance in assessing the wind energy potential of a particular area and provides important information on the efficiency of the use of wind turbines in terms of the coherence of the wind energy flow schedule with the energy load schedule of consumers [15]. In Fig. 2b shows the annual wind speed variation at the 33158 grid node located in the northwest of Marrakesh - Safi region. The analysis showed that the model predicts the maximum value of the mean monthly wind speed in July $\left(6.1 \mathrm{~m} \cdot \mathrm{s}^{-1}\right)$, and the minimum in December $\left(4.2 \mathrm{~m} \cdot \mathrm{s}^{-1}\right)$. Also, you can note the secondary maximum wind speed in May $\left(5.9 \mathrm{~m} \cdot \mathrm{s}^{-1}\right)$. In general, the highest wind speed models predict from April to August.

The reason for increasing the wind speed in this area in the warm half-year is the growth of baric gradients on the Atlantic coast as a result of seasonal changes in the pressure field. In the recurrence of Circulation Weather Types in Morocco, this is manifested in the prevalence of the repeatability of types in the summer (more than $95 \%$ of cases in 1960-2006), which are characterized by the strengthening of the Azores High, which leads to an increase in baric gradients in the coastal zone [20]. Another factor that contributes to increasing the wind speed in the area during the summer months is the development of the breezy circulation.

Analysis of the annual run of DMWS showed that it has a similar wind speed character (Fig. 2b). Its maximum mean monthly value the model is predicted in July $\left(9.0 \mathrm{~m} \cdot \mathrm{s}^{-1}\right)$, and the minimum in December $\left(6.1 \mathrm{~m} \cdot \mathrm{s}^{-1}\right)$.

The magnitude of $G$ varies from 0.43 (in January) to 0.58 (in September). The highest values correspond to the month, in which, along with elevated wind speeds, models predict a large difference between the daily maximum wind speed and the mean wind speed.

\subsection{Wind power density in 2021-2050}

Analysis of the mean wind power density at a height of $50 \mathrm{~m}$ for the period 2021-2050 (Fig. 2c) showed that the eastern half of the region will be characterized as a territory with poor wind power class (up to $200 \mathrm{~W} \cdot \mathrm{m}^{-2}$ ). An area with good class (more than $400 \mathrm{~W} \cdot \mathrm{m}^{-2}$ ) will be a strip lying along the coast from Cap Sim to the southern border of the region, where its width will reach approximately $40 \mathrm{~km}$. The highest wind potential the model is predicted on the coast between Essaouira and Cap Tafelny, where the wind farms Essaouira-Amogdoul and Tarfayer are located (more than $600 \mathrm{~W} \cdot \mathrm{m}^{-2}$ ).

The distribution of wind power density at $100 \mathrm{~m}$ height above the earth's surface showed that the territory having good wind class will be a strip about $50 \mathrm{~km}$ wide, located along the Atlantic coast (Fig. 2d), and directly in the area where wind farms are located predict the value of $\mathrm{Ne}$ above $800 \mathrm{~W} \cdot \mathrm{m}^{-2}$. 


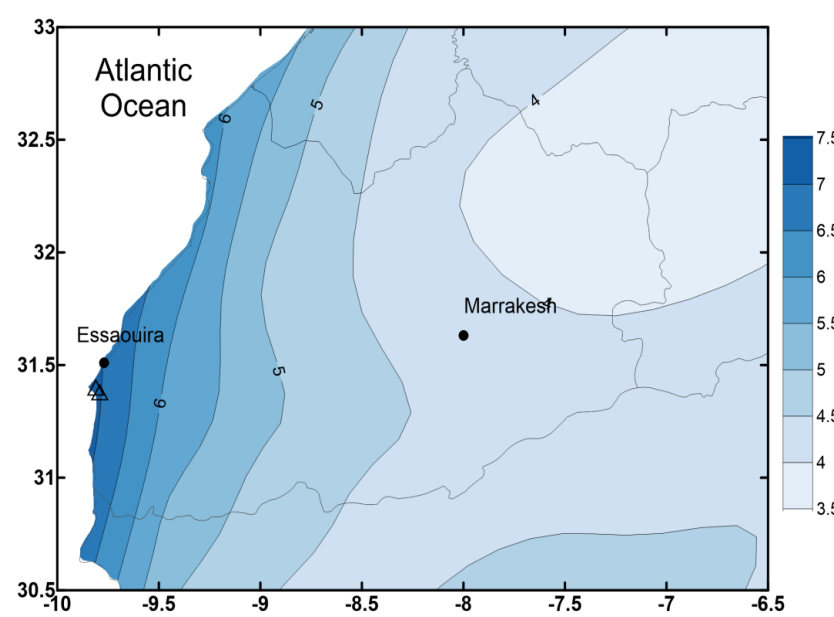

a)

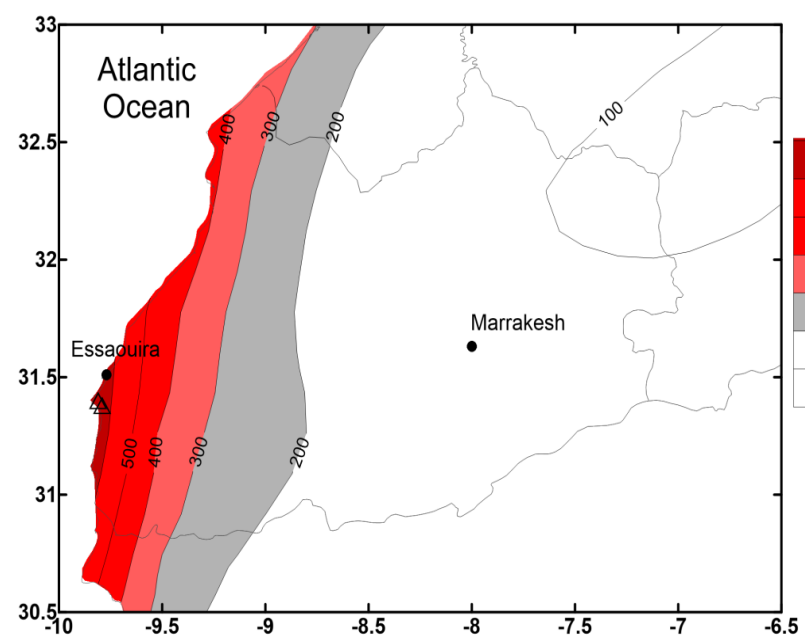

c)

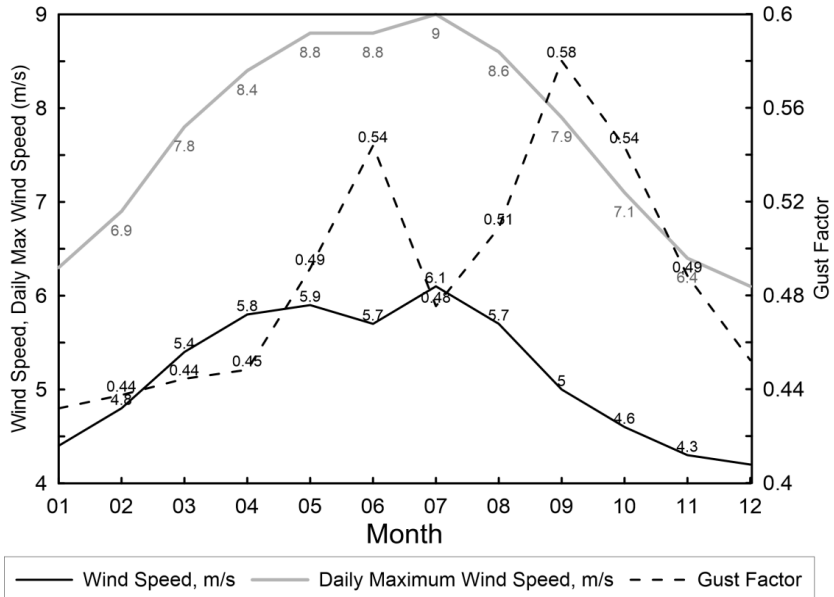

b)

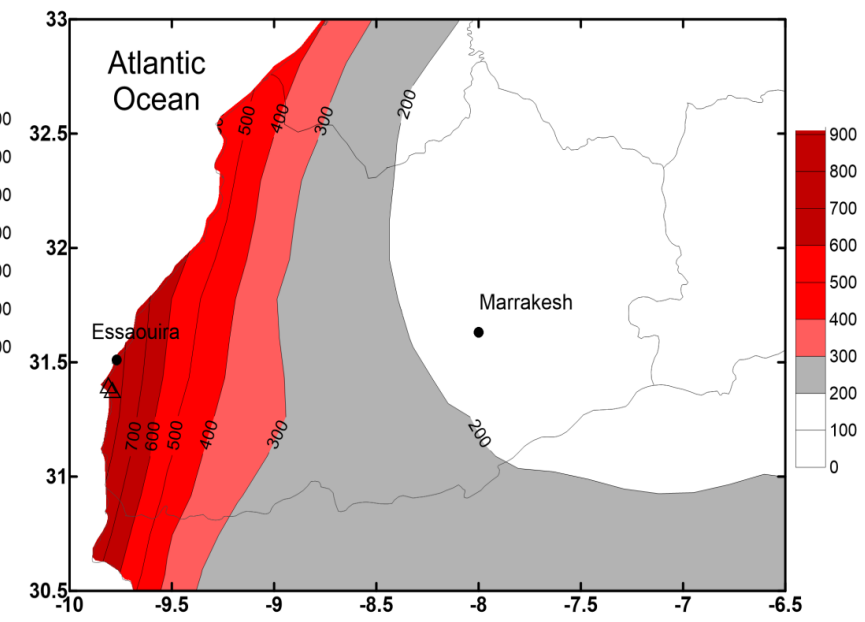

d)

Fig. 2 - The ensemble average wind speed $\left(\mathrm{m} \cdot \mathrm{s}^{-1}\right)$ at a height of $10 \mathrm{~m}$ for the period 2021-2050 $(a)$, the annual run of wind speed $\left(\mathrm{m} \cdot \mathrm{s}^{-1}\right)$, daily maximum wind speed $\left(\mathrm{m} \cdot \mathrm{s}^{-1}\right)$ and gust factor in the 33158 grid node of model for the period 2021-2050 $(b), N e\left(\mathrm{~W} \cdot \mathrm{m}^{-2}\right)$ in 2021-2050 at $50 \mathrm{~m}$ height $(c), \mathrm{Ne}\left(\mathrm{W} \cdot \mathrm{m}^{-2}\right)$ in 2021-2050 at 100 height $(d)$

\section{CONCLUSIONS}

An analysis of the results of modeling the wind speed in 2021-2050 showed that in the coastal areas of the region, favorable conditions for the development of wind power will continue; models predict the highest wind speeds in the section of the Atlantic coast between Cap Sim and Cap Tafelny.

The highest wind speeds will be observed in the summer period, which coincides with an increase in the use of electricity by consumers for cooling.

By value of the wind power density at a height of $50 \mathrm{~m}$ good wind class will have territory, which located along the coast from Cap Sim to the southern border of the region. The area in which the Essaouira-Amogdoul and Tarfayer wind farms is located will have the outstanding wind power class. Thus, in 2021-2050 on the territory of Marrakesh Safi region, we can expect favorable conditions for the placement of large wind turbines with a nominal capacity of up to $10 \mathrm{MW}$, which if connections can form larger wind farms.

Today, new approaches to downscaling of the RCMs are being introduced, allowing more detailed information on the future climate to be obtained. For simulate of wind speed, reducing the spatial resolution of model calculations is one of the most important steps, because wind speed is a very variable meteorological element. Thus, future research will focus on obtaining more detailed information of wind speed, taking into account new model calculations with a higher spatial resolution.

\section{REFERENCES}

1. Concentrating Solar Power for the Mediterranean Region. Final Report by German Aerospace Center. Available at: https://www.dlr.de/Portaldata/1/Resources/portal_news/new sarchiv2008_1/algerien_med_csp.pdf (accessed 7 May 2021).

2. Alhamwi, A., Kleinhans, D., Weitemeyer, S., et al. (2015). Moroccan National Energy Strategy reviewed from a 
meteorological perspective. Energy Strategy Reviews, 6, pp. 39-47. https://doi.org/10.1016/j.esr.2015.02.002

3. Morocco plans to add $10 \mathrm{GW}$ of power from renewable energy sources by 2030. Report: Morocco 2018. Available at: https://oxfordbusinessgroup.com/analysis/viablealternative-plans-add-10-gw-power-renewable-sources2030 (accessed 7 May 2021)

4. Accelerating the development of renewables on the $M V$ market in Morocco. A Pöyry Report to RES4MED. Available at: https://www.res4med.org/wpcontent/uploads/2018/07/RES4MED Accelerating-thedevelopment-of-renewables-on-the-MV-market-inMorocco Jun2018.pdf (accessed 7 May 2021).

5. Nfaoui, $\bar{H}$., Buret, J. \& Sayigh, A.A.M. (1998). Wind characteristics and wind energy potential in Morocco. Solar Energy, 63(1), pp. 51-60.

6. Raihani, A., Hamdoun, A., Bouattane, O. et al. (2012). Toward an accurate assessment of wind energy platform of Mohammedia city, Morocco. Engineering Science and Technology: An International Journal, 2(5), pp. 951-958.

7. Sadouk, A. \& Djebli, A. (2015). Wind Energy Potential in Tetuan City Northern of Morocco. International Journal of Science and Research, 4(10), pp. 689-693.

8. Morocco Regions. Statoids. Available at: http://www.statoids.com/uma.html (accessed 7 May 2021)

9. Schinke, B., Klawitter, J. et al. (2016). Background Paper: Country Fact Sheet Morocco Energy and Development at a glance. Bonn: Germanwatch.

10. IS-ENES climate4impact portal. Available at: https://climate4impact.eu/ (accessed 7 May 221)

11. El Hadri, Y. et al. (2019).Wind energy land distribution in Morocco in 2021-2050 according to RCM simulation of CORDEX-Africa project. Arab J Geosci, 12, pp. 753. https://doi.org/10.1007/s12517-019-4950-7

12. Wind farms databases. The Wind Power). Available at: https://www.thewindpower.net/index.php (accessed 5 May 2021)

13. Udalov, S.N., \& Zubova, N.V. (2013). Simulation of Wind
Speed in the Problems of Wind Power. Journal of Siberian Federal University. Engineering \& Technologies, 6(2), pp. 150-165.

14. Kim, J., Waliser, D.E. et al. (2014). Evaluation of the CORDEX-Africa multi-RCM hindcast: systematic model errors. Clim Dyn., 42(5-6), pp. 1189-1202. https://doi.org/10.1007/s00382-013-1751-7

15.El Hadri, Y., Khoklov, V.N. \& Slizhe, M.O. (2018). Regional climate models projections of wind speed in Morocco for period 2020-2050. Asian Journal of Environment \& Ecology, 6(3), pp.1-7. https://doi.org/ 10.9734/AJEE/2018/41112

16. Tong, W. (2010). Wind Power Generation and Wind Turbine Design. Southampton: WIT Press.

17. Donat, M.G. et al. (2011). Future changes in European winter storm losses and extreme wind speeds inferred from GCM and RCM multi-model simulations. Nat. Hazards Earth Syst. Sci., 11, pp. 1351-1370. https://doi:10.5194/nhess-11-1351-2011

18. Graybeal, D.Y. (2006). Relationships among daily mean and maximum wind speeds, with application to data quality assurance. Int. J. Climatol., 26, pp. 29-43. https://doi.org/ $10.1002 /$ joc. 1237

19. Harris, A.R. (2016). On Establishing a Climatology f Gust Factors and Assessing Their Ability to Forecast Wind Gusts in Milwaukee, WI. Theses and Dissertations. The University of Wisconsin. Available at: https://dc.uwm.edu/etd/1150 (accessed 5 May 2021)

20. Born, K., Fink, A.H. \& Knippertz, P. (2010). Meteorological processes influencing the weather and climate of Morocco. In: Speth, P., Christoph, M., Diekkrüger, B., Bollig, M., Fink, A.H., Goldbach, H., Heckelei, T., Menz, G., Reichert, B., Rössler, M. (eds.). Impacts of Global Change on the Hydrological Cycle in West and Northwest Africa. Springer, pp. 150-163. http://dx.doi.org/10.1007/978-3-642-12957-5

\title{
ОЦІНКА ВІТРОВОГО ПОТЕНЦІАЛУ \\ РЕГІОНУ МАРОККО МАРРАКЕШ - САФИ У 2021-2050 РР. НА ОСНОВI ПРОГНОЗІВ РКМ ПРОЕКТУ СОRDEХ-АФРИКА
}

\author{
Ель Хадрі Ю., Сліже М.О., Серницька К.
}

\author{
Одеський державний екологічний університет, \\ вул. Львівська, 15, 65016, Одеса, Украӥна, magribinets@ukr.net
}

\begin{abstract}
Перехід до вироблення елктроенергіi 3 поновлюваних джерел сьогодні $є$ одним 3 найбільш актуальних напрямків в енергетичній сфері. Сьогодні на території регіону Марракеш - Сафі Королівства Марокко розміщена одна 3 найбільших в країні вітроелектростанція Tarfayer, а також знаходиться в стадії будівництва станція EssaouiraAmogdoul. Тому, значний інтерес представляє стан вітрових ресурсів у даному регіоні в найближчі десятиліття. Метою дослідження є визначення особливостей просторового розподілу швидкості вітру в 2021-2050 pp. у регіоні, а також розподіл питомої потужності вітрового потоку на висотах 50 і 100 м. Оцінка вітрових характеристик у 2021-2050 рр. була виконана на основі розрахунків середньомісячних значень швидкості вітру і добового максимуму швидкості вітру на висоті 10 м регіональних кліматичних моделей проекту CORDEX-Africa. Визначення вітрового класу території виконувалось на основі величини питомої потужності вітрового потоку на висоті 50 i $100 \mathrm{M}$. Результати модельних розрахунків показали, що середня за ансамблем швидкість вітру для періоду 2021-2050 pp.
\end{abstract}




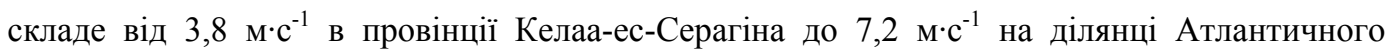
узбережжя між мисом Сім і мисом Тафельні. На розподіл по території впливатиме близькість до океану, моделі передбачають найвищі швидкості вітру на узбережжі, а при просуванні вглиб регіону швидкість вітру буде зменшуватися. Аналіз результатів моделювання показав, що в прибережних районах збережуться сприятливі для розвитку вітроенергетики умови, найбільш високі швидкості вітру моделі прогнозують на ділянці Атлантичного узбережжя між мисом Сім і мисом Тафельні. За величиною питомої потужності вітрового потоку значними вітровими запасами буде володіти територія, яка лежить уздовж узбережжя від мису Сім до південної межі регіону, а район розміщення електростанцій Essaouira-Amogdoul i Tarfayer за прогнозами моделей буде мати класс, який характеризується видатними вітровими ресурсами.

Keywords: CORDEX-Африка; швидкість вітру; питома потужність вітрового потоку; регіональні кліматичні моделі, Марокко; Марракеш - Сафі.

\title{
ОЦЕНКА ВЕТРОВОГО ПОТЕНЦИАЛА РЕГИОНА МАРОККО МАРРАКЕШ - САФИ В 2021-2050 ГГ. НА ОСНОВЕ ПРОГНОЗОВ РКМ ПРОЕКТА CORDEX-AFRICA
}

\author{
Эль Хадри Ю., Слиже М.О., Серницкая К. \\ Одесский государственный экологический университет, \\ ул. Львовская,15 ,65016, Одесса, Украина, magribinets@ukr.net
}

В настоящее время на территории региона Марракеш - Сафи Королевства Марокко размещена одна из крупнейших в стране ветроэлектростанция Tarfayer, a также находится на стадии строительства станция Essaouira-Amogdoul. Поэтому значтельный интерес представляет состояние ветровых ресурсов в данном регионе в ближайшие десятилетия. Целью исследования является определение особенностей пространственного распределения скорости ветра в 2021-2050 годах в регионе, а также распределения удельной мощности ветрового потока на высотах 50 и 100 м для определения ветрового класса данной территории в ближайшем будущем. Оценка ветровых характеристик в 2021-2050 гг. была выполнена на основе расчетов среднемесячных значений скорости ветра и суточного максимума скорости ветра на высоте 10 м региональных климатических моделей проекта CORDEX-Африка. Определение ветрового класса территории производилось на основе значений удельной мощности ветрового потока на высотах 50 м и 100 м. Анализ результатов моделирования показал, что в прибрежных районах региона сохранятся благоприятные для развития ветроэнергетики условия, наиболее высокие скорости ветра модели прогнозируют на участке Атлантического побережья между мысом Сим и мысом Тафельни. По величине удельной мощности ветрового потока значительными ветровыми запасами будет обладать территория, лежащая вдоль побережья от мыса Сим до южной границы региона, а районы размещения электростанций Essaouira-Amogdoul и Tarfayer, по прогнозам моделей, будут обладать классом с выдающимися ветровыми ресурсами.

Ключевые слова: CORDEX-Африка; скорость ветра; удельная мощность ветрового потока; региональные климатические модели; Марокко, Марракеш - Сафи.

Подання до редакиії : 08. 05. 2021 